\title{
A Red List of mites from the suborder Uropodina (Acari: Parasitiformes) in Poland
}

\author{
Agnieszka Napierała $^{1}$ (D) · Zofia Książkiewicz-Parulska · Jerzy Błoszyk ${ }^{1,2}$
}

Received: 13 December 2017 / Accepted: 14 August 2018 / Published online: 23 August 2018

(c) The Author(s) 2018

\begin{abstract}
This article presents a Red List of mite species from the suborder Uropodina (Acari: Parasitiformes) occurring in Poland. Evaluation of the conservation status of the analyzed species was compiled on the basis of new criteria, which may also be applied to other groups of soil fauna. The authors employ the names of categories proposed by the International Union for Conservation of Nature (IUCN). One of our aims was to review the IUCN criteria to ascertain whether they are applicable in an attempt to assess the danger of extinction of soil invertebrates, and to see whether the criteria can be adapted to make such an assessment. The analyzed material contained 93 mite species obtained from 16,921 soil samples, which were collected between 1961 and 2017 in the whole area of Poland. The categories were assigned to species on the basis of the frequency of the species, but also other factors were taken into account, such as microhabitat specificity, vulnerability to detrimental conditions, and shrinking of local populations. One of the analyzed species can now be regarded as extinct, over $25 \%$ of the species ( $26 \mathrm{spp}$.) were labeled as critically endangered, and most of them (33 spp.) were categorized as vulnerable - the other species were assigned to the categories endangered (13 spp.), near threatened (10 spp.), and least concern (10 spp.).
\end{abstract}

Keywords Invertebrates $\cdot$ Arthropods $\cdot$ Soil fauna $\cdot$ Threatened species $\cdot$ Extinction $\cdot$ IUCN

\section{Introduction}

The deteriorating condition of the natural environment—which is evident in the shrinkage of natural habitats, a decrease in population abundance of many species, and, as a result, an overall decline in biodiversity - is the major reason why so many species of the European fauna have been listed in the European Red List, which is part of the IUCN Red List of Threatened Species. Among the endangered species there are species from all groups of vertebrates. As for invertebrates, among the endangered species there are $44 \%$ of all

Agnieszka Napierała

agan@amu.edu.pl

1 Department of General Zoology, Faculty of Biology, AMU, ul. Umultowska 89, 61-614 Poznan, Poland

2 Natural History Collections, Faculty of Biology, AMU, ul. Umultowska 89, 61-614 Poznan, Poland 
fresh-water mollusks and $20 \%$ of some terrestrial mollusks, $15 \%$ of dragonflies, $11 \%$ of saproxylic beetles, and $9 \%$ of butterflies (European Commission 2017).

This clearly suggests that the assessment of the extent to which species are endangered focuses mainly on vertebrates and the invertebrate species that can be easily found in the examined area. There is virtually no research into the scale of extinction of microscopic arthropods, especially those inhabiting soil. It is impossible to observe such organisms directly in the examined area for a long period of time, which also means that it is impossible to determine the stability and extent of the changes occurring in populations of the respective species (Błoszyk 1999; Niedbała 2000; André et al. 2002). There is no doubt that this holds for soil mesofauna, and mites (Acari) are among them. Soil habitats, and other ecosystem components, are often polluted causing environmental degradation, which can have a tremendous impact on species composition and the abundance of mite communities in a given area (Kaczmarek and Seniczak 1994, 1998; Napierała 2008; Napierała et al. 2015b). What is more important, soil mites are pivotal in nutrient cycling, soil formation, and decomposition of organic matter, which in turn can affect soil fertility and plant growth, and therefore these organisms are also important for economic reasons (Jeffery and Gardi 2010).

Increasing anthropopressure and the subsequent soil contamination, soil erosion, salinization, physical degradation, and climate change are responsible for that fact that many species of soil fauna have become threatened (Jeffery and Gardi 2010). Moreover, it has already been proven that overall soil biodiversity is in decline (Jones et al. 2012). For this reason special attention is paid to soil biodiversity by the European Union, which can be seen in the EU Biodiversity Strategy until 2020 (European Commission 2011). The effort aimed at realization of the strategy will be continued in order to fill this void in the research, including the research into the mapping and assessing ecosystem services in Europe, which will help to learn more about the influence of climate changes on biodiversity, and the role of soil biodiversity in delivering key ecosystem services, such as carbon sequestration and food supply. The commitment of the EU to soil biodiversity protection has been further supported by the International Convention on Biological Diversity, where its importance as a key player in sustainable agriculture was strengthened during the 2010 conference of the parties to the convention in Nagoya, Japan (Jones et al. 2012).

The Red Lists of endangered species rarely contain any species of soil fauna, especially arachnids (Arachnida). The IUCN Red List of Threatened Species (2017) contains only $0.24 \%$ species from this class out of all 102,248 species described so far (Chapman 2009). Various species of spiders constitute the most numerous group of assessed species (199 spp. of Araneae, but also 21 spp. of Opiliones, and 13 spp. of false scorpions, Pseudoscorpiones) (Red List Category summary for all animal classes and orders; IUCN Red List of Threatened Species 2017). Only a few species from the other orders, such as whip spiders (Amblypygi), scorpions (Scorpiones), and short-tailed whip scorpions (Schizomida), have been classified as endangered (IUCN Red List of Threatened Species 2017). As for mites, there is only one species that has been classified as endangered $(\mathrm{EN})$, namely the moss mite (Oribatida) Scheloribates evanescens Wallwork, which was classified in 2014 (IUCN Red List of Threatened Species 2017). There are only two species of soil invertebrates inhabiting Poland that have been included in the 'Polish red data book of animals: invertebrates' (Głowaciński and Nowacki 2004), i.e., one of the Opiliones (Siro carpathicus) and one of the Pseudoscorpiones (Neobisium polonicum), both described by Prof. Jan Rafalski from Bieszczady (SE Poland). These two species have been classified as EN, and since October 2014 they have been legally protected in Poland. In 2008 the third volume of Fauna Polski [The Fauna of Poland] (Bogdanowicz et al. 2008) was published, in which 
the authors provide a list of mite species occurring in Poland. However, the list gives no information about the conservation status of the enumerated species, though the list contains information which can be helpful to estimate whether a given species is common and how frequently it occurs.

The fact that mites are quite susceptible to changes caused by industry and agriculture, and all temperature and soil moisture fluctuations that they cause, makes these organisms perfect bioindicators of soil health (Moore et al. 1984; Błoszyk 1998a, b; Gardi et al. 2002; Migliorini et al. 2004; Aspetti et al. 2010). However, there are very few studies that present results of regular long-term quantitative research into soil fauna, which is essential to determine the trajectory of changes in populations of soil fauna (Malmström et al. 2009). The numerous acarological studies conducted in Poland over the last 50+years are the only exception in this respect (Niedbała 1972, 1976, 1990; Błaszak 1974; Rajski 1967, 1969; Kaźmierski 1980; Niedbała et al. 1981; Błoszyk 1983, 1999; Michocka 1987; Kaliszewski and Sell 1990; Siuda 1993; Gabryś and Mąkol 1995; Gabryś 1996; Wiśniewski 1997; Mąkol 2005; Gwiazdowicz 2007). For this reason Poland is probably the only country in which distribution of mites has been analyzed so comprehensively.

Because mites from the suborder Uropodina have been already thoroughly described based on long-term quantitative research (Athias-Binche 1977a, b, c, 1981a, b, c, 1982a, b, 1983; Błoszyk 1983, 1984, 1999; Wiśniewski and Hirschmann 1993; Wiśniewski 1997; Mašán 2001; Błoszyk et al. 2003a), the current study presents the Red List of threatened species of soil mites in Poland, and an analysis of the IUCN criteria for this group of organisms. In 2011, Cardoso et al. (2011) made an attempt to adapt the IUCN criteria to classify invertebrates according to the conservation status. Cardoso et al. (2011) provided a critical review of the IUCN criteria focusing on the applicability of these criteria in establishing the conservation status of invertebrates, and they proposed how to effectively adapt the criteria. We decided to go a bit further and also analyze the IUCN criteria to see whether they can be helpful in estimating the conservation status of soil mesofauna, and used mites from the suborder Uropodina as a model group. Furthermore, this study also presents an assessment of the conservation status of Uropodina species in Poland, and a classification of the species according to the IUCN criteria. Analysis of the population abundance of the discussed species from this group and the assessment of their conservation status was carried out on the basis of direct observations plus data from previous studies.

\section{Mites from the suborder Uropodina as a model group}

Cardoso et al. (2011) analyzed the IUCN criteria and the applicability of these criteria in establishing the conservation status of invertebrates, and they also suggested how to effectively modify these criteria. They too believe that most of these criteria, which are usually assigned on the basis of species abundance, are not applicable to invertebrates because there is no effective method of estimating abundance of populations of any terrestrial species of invertebrates in the natural environment (Kozlowski 2008; Cardoso et al. 2011). Regardless of the sampling method, the final results will always diverge from the actual abundance of the species (Niedbała 2000; André et al. 2002). This can be observed especially in the case of very small invertebrates which live in specific microhabitats, and they can form local populations within an area of $1 \mathrm{~m}^{2}$ (Napierała 2008). This applies with no doubt to mites (Acarina), as they are small arachnids inhabiting, e.g., soil and litter of forest ecosystems, as well as open environments and unstable microhabitats (such as bird nests, mammal nests, anthills, dead wood, and excrements of vertebrates). However, little has 
been done so far to establish the conservation status of species from this group of arachnids with its worldwide distribution. Many of these species were described on the basis of material collected only in one ground plot (does this mean high endemism?), sometimes with a low number of specimens, occasionally just a few (does this mean low abundance?). Moreover, many species were found only once and, despite intensive subsequent exploration, have never been recorded since. Does this mean that they have become extinct? Are the examined microhabitats the best places, and is the time the best to find these species? The answer to each of these questions can be proper. The major problem here is of course the size of mites, which makes direct observation impossible in any site. Thus, gaining information about the actual distribution and abundance of local populations is extremely hard and laborious. During the processes of collecting samples, extracting specimens, and until preparing microscopic slides it is unclear what species the collected samples contain. Research conducted so far focuses mainly on the description of new taxa, disregarding their biology, ecology, and zoogeography-for this reason the available accounts about these matters are rather obscure and fragmentary. Mites from the suborder Uropodina are among the exceptions in this respect (Athias-Binche 1977a, b, c, 1981a, b, c, 1982a, b, 1983; Błoszyk 1984, 1985, 1999; Wiśniewski and Hirschmann 1993; Wiśniewski 1997; Mašán 2001; Błoszyk et al. 2003a). These arachnids, with highly diversified morphology, have been the primary focus of interest for a long time for many acarologists, which is evident in the extensive research conducted so far. The data presented in earlier studies and our direct observations of these mites conducted for over 50 years allow the use of Uropodina as a model group to verify the IUCN criteria, and to propose certain modifications in relation to what is offered by Cardoso et al. (2011).

Mites from the suborder Uropodina are a well-known group in Europe. The number of European species that have been identified and described hitherto exceeds 440 (Wiśniewski and Hirschmann 1993). A rough estimate of the number of Uropodina species in Poland is 150 (Wiśniewski 1997) or 137 (Błoszyk 1999, 2008). One of the most specific characteristics of Uropodina is their great diversity in habitat preferences. The species living in soil and litter of forest ecosystems constitute over $60 \%$ of the Polish Uropodina fauna, whereas the other species (30\%) inhabit unstable microhabitats, such as tree hollows, rotten tree trunks, anthills, bird and mammal nests, and animal feces, and about $9 \%$ occur in open habitats such as meadows, sandhills, xerophilous grasses etc. (see, e.g., Błoszyk 1999; Błoszyk et al. 2003a; Napierała and Błoszyk 2013).

The highest abundance of Uropodina occurs in places with a high percentage of organic matter such as litter of deciduous forests (frequency up to $10,000 \mathrm{specimens} / \mathrm{m}^{2}$ ) and dead wood and compost (Koehler 1997, 1999). Uropodina mites also have different trophic requirements. Many species are saprophagous, which means that they feed on dead organic matter from plants and animals (Karg 1993). Other species are mycetophagous, which feed on spores and mycelia (Faasch 1967; El-Banhawy et al. 1998). Apart from these, there are also predatory species, which hunt for nematodes, insect larvae, and oligochaetes (Faasch 1967; Ito 1971; El-Banhawy et al. 1998; Koehler 1997, 1999).

Their dispersal abilities and reproduction strategies depend on the habitat in which they live (e.g., Błoszyk 1999). It has been shown in many studies (e.g., Mašán 2001; Błoszyk et al. 2003a, 2004; Napierała and Błoszyk 2013; Napierała et al. 2016) that unstable microhabitats are usually populated by both males and females, whereas soil habitats are often dominated by parthenogenetic species, which are characterized by immense reduction of males in their populations (Norton et al. 1993; Błoszyk et al. 2004). Deutonymphs of some species, especially those inhabiting unstable merocenoses, have developed the ability of passive dispersion, by means of phoresy (Faasch 1967; Athias-Binche 1984, 1993, 1994). 
They can be carried by various groups of insects, e.g. by myriapods, as well as in fur mammals and bird feathers (Gwiazdowicz 2000; Bajerlein and Błoszyk 2004; Bajerlein et al. 2006; Napierała et al. 2015a).

Uropodina mites have also very specific habitat preferences. Looking at the discerned ecological elements of Poland one can say that most of Uropodina mites are stenobiotic and oligobiotic (70\%), whereas only 6\% are eurybiotic (Błoszyk 1999; Błoszyk et al. 2003a, 2004; Napierała 2008). Due to their narrow ecological tolerance Uropodina mites very quickly react to fluctuations in environmental conditions (both abiotic and biotic) by changes in species composition and abundance (Błoszyk 1999; Napierała 2008; Napierała et al. 2015b). For this reason mites from this group can be used as bioindicators of changes in the soil environment and, of course, they can be used to evaluate soil quality.

\section{Materials and methods}

The material for the analysis comprises 16,921 soil samples collected between 1961 and 2017 regardless of the season, by different researchers, in the whole area of Poland. Out of all soil samples 39\% (6599) were qualitative samples-sieved litter and soil, as well as nonsieved samples of dead wood (with $0.5-1 \mathrm{~L}$ volume), and $61 \%(10,322)$ were quantitative samples with the size between 16 and $100 \mathrm{~cm}^{2}$. The quantitative samples were collected with a metal frame of $4 \times 4 \mathrm{~cm}$, or with a cylinder at the depth of up to $10 \mathrm{~cm}$ (Błoszyk 1999). The material was harvested from three types of environment, i.e., open, forest, and merocoenoses. The samples were collected evenly in the whole area of Poland (Fig. 1). This method allows to estimate the approximate distribution of species in the examined areas inhabited by local populations (Fig. 1) (Błoszyk 1999). These samples contained 93 species of Uropodina, which were represented by 158,051 specimens.

Our analysis is also based on the data stored in the digital database of Natural History Collections at the Faculty of Biology at Adam Mickiewicz University in Poznań, and data from earlier studies.

\section{Criteria for classification of threatened species of mites from the suborder Uropodina according to the IUCN categories}

This article employs the terms of categories proposed by the IUCN (2001, Categories and Criteria, version 3.1). Moreover, the paper also is a critical evaluation of the IUCN criteria used for establishing conservation status in terms of their usage to evaluate the status for mites from the suborder Uropodina. The new criteria proposed here may be used also for other groups of soil fauna organisms.

On the basis of our long-term research and the evidence available in the literature (Błoszyk 1983, 1999; Wiśniewski and Hirschmann 1993; Mašán 2001; Błoszyk et al. 2003a; Napierała and Błoszyk 2013), we claim that the parameters of dominance (D), frequency (F), and ecological importance (Q) are the most significant criteria in the evaluation of the conservation status of mites from the suborder Uropodina (see Kasprzak and Niedbała 1981). In the current study we have estimated the conservation status for each of the 93 Uropodina species listed in the study.

The analysis of the abundance and occurrence frequency of species in the samples employs dominance (D) and frequency (F) as biocenotic indices (Table 1). Moreover, 


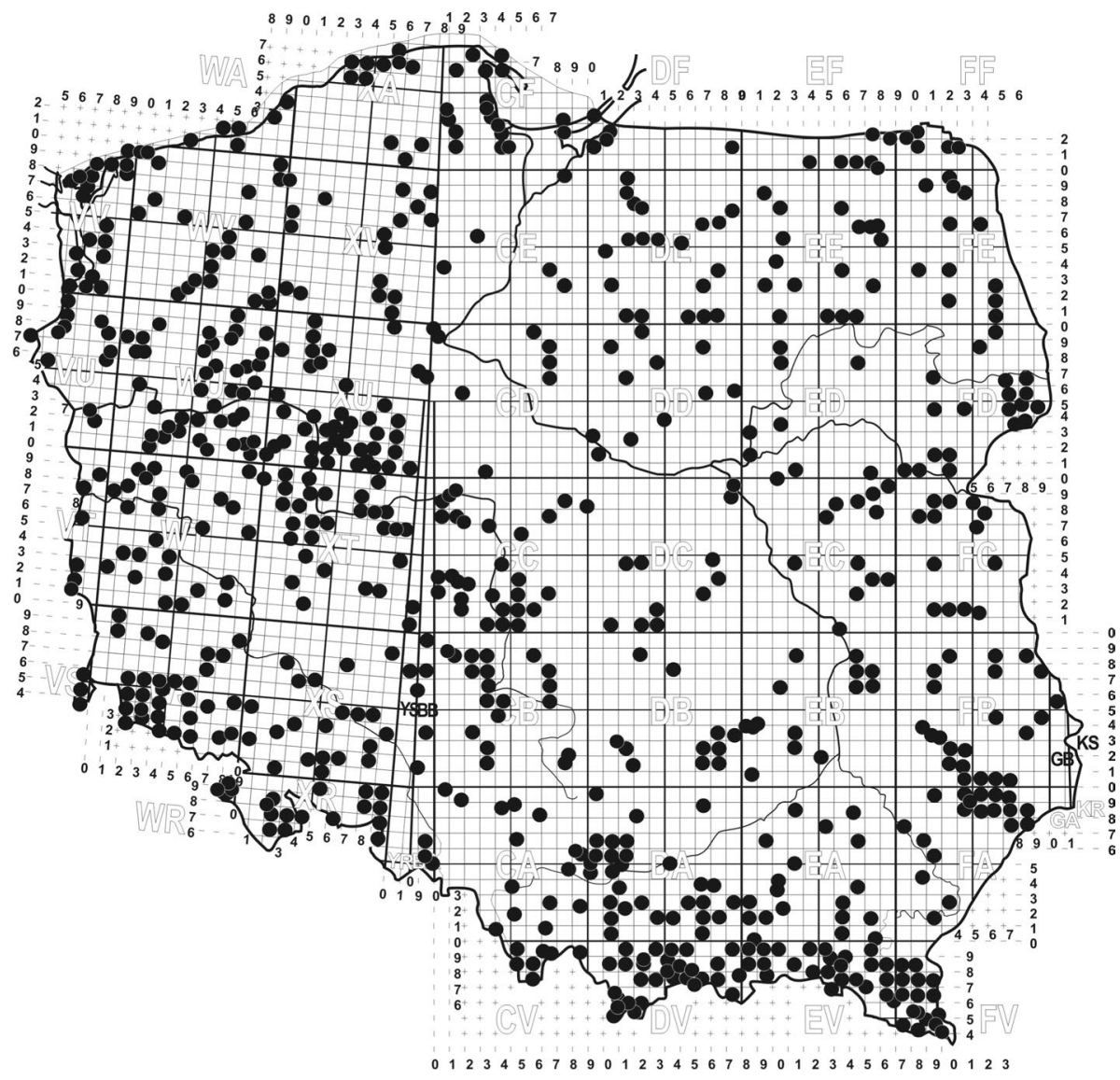

Fig. 1 Areas of Poland where the material for the analysis was collected

Table 1 Evaluation of frequency and abundance of species calculated for the dominance index (D) and frequency index (F)

\begin{tabular}{lllll}
\hline Dominance & \multicolumn{2}{l}{ Frequency } & & \\
\cline { 2 - 5 } & Very frequent & Frequent & Rare & Sporadic \\
\hline Abundant & D5-D4; F5-F4; & D5-D4; F3 & D5-D4; F2 & D5-D4; F1 \\
Numerous & D3; F5-F4; & D3; F3; & D3; F2 & D3; F1 \\
Few & D2; F5-F4; & D2; F3 & D2; F2 & D2; F1 \\
Very few & D1; F5-F4; & D1; F3 & D1; F2 & D1; F1 \\
\hline
\end{tabular}

the analysis also takes into account the synthetic index $Q=\sqrt{ } D * F$, where ' $Q$ ' stands for the index of ecological importance (Kasprzak and Niedbała 1981).

The adopted categories of zoocenological indices (after Kasprzak and Niedbała 1981) are: 


\begin{tabular}{|c|c|c|c|c|c|c|c|c|}
\hline \multicolumn{3}{|c|}{ Frequency $(\mathrm{F})$} & \multicolumn{3}{|c|}{ Dominance (D) } & \multicolumn{3}{|c|}{ Ecological importance $(\mathrm{Q})$} \\
\hline F5 & Euconstants & $>30 \%$ & D5 & Eudominants & $>10 \%$ & Q5 & Very frequent & $>38.73$ \\
\hline F4 & Constants & $15.1-30 \%$ & D4 & Dominants & $5.1-10 \%$ & Q4 & Frequent & $21.32-38.73$ \\
\hline F3 & Subconstants & $7.1-15 \%$ & D3 & Subdominants & $2.1-5 \%$ & Q3 & Rare & $10.35-21.21$ \\
\hline $\mathrm{F} 2$ & Accessory species & $3-7 \%$ & D2 & Residents & $1.1-2 \%$ & Q2 & Sporadic & $3.87-10.25$ \\
\hline $\mathrm{F} 1$ & Accidents & $<3 \%$ & D1 & Subresidents & $<1 \%$ & Q1 & Very sporadic & $<3.87$ \\
\hline
\end{tabular}

Also other factors were taken into account, for example, the fact that a species lives in a specific microhabitat, its ecological vulnerability (e.g., colonization of unique habitats), and the shrinking of local populations observed by the authors during the research period. The analysis also takes into consideration whether a given species is common or rare, the extent to which the species is threatened, and the pace of shrinking of the environment inhabited by the species, as these factors can have a direct impact on occurrence of Uropodina mites in such places. Among such habitats there are, for example, shrinking wetland areas, xerothermic grasslands, old forests ( $>120$ years old), tree hollows, nests of some species of birds, etc. The species associated with such habitats have been classified with the lowest value of the 'habitat' parameter $(\mathrm{H})$. Additional parameters are geographic range $(\mathrm{Gr})$, which can be broad or restricted, the dynamics of geographic range (Dgr), which can be stable or shrinking, and population reduction $(\mathrm{Pr})$, which shows the potential reduction or increase in the abundance of local populations of a species. These parameters had the following values:

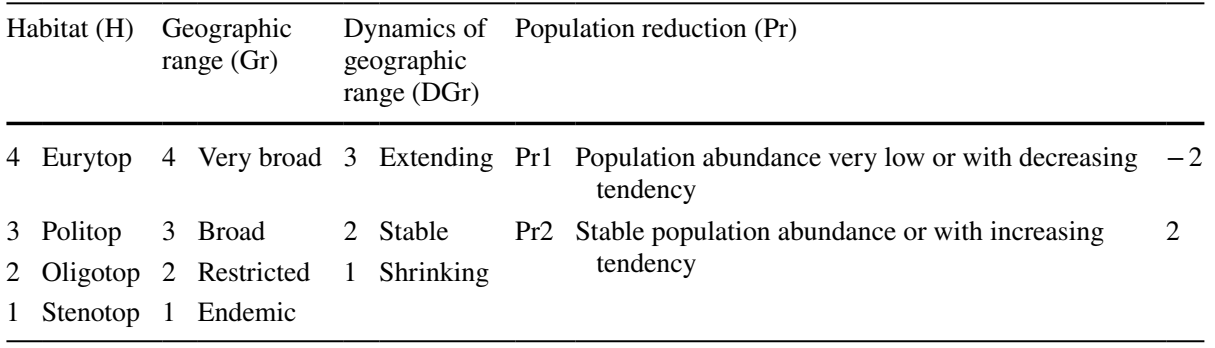

Sources: (H) Błoszyk et al. (2004), Napierała and Błoszyk (2013), (Gr) Wiśniewski and Hirschmann (1993), Błoszyk (1999), Mašán (2001), Błoszyk et al. (2003a); unpublished data, (DGr) Wiśniewski and Hirschmann (1993), Błoszyk (1999), Mašán (2001), Błoszyk et al. (2003a), unpublished data

The sum of these parameters stands for the value of the Endangered Index (EnI), which was used to establish the categories of threatening for the listed Uropodina species: $\mathrm{EnI}=\mathrm{F}+\mathrm{D}+\mathrm{Q}+\mathrm{H}+\mathrm{Gr}+\mathrm{DGr}+\mathrm{Pr}$.

\section{Critical overview of the IUCN criteria in evaluation of conservation status of soil mesofauna}

The following sub-sections show how to adapt the IUCN categories and criteria in evaluation of the conservation status of soil mites, with examples of Uropodina mites found in Poland. 


\section{Criterion A: population reduction}

To evaluate the reduction of mite populations it is possible to use a simple index of constancy (especially in quantitative analyses) or to measure the frequency of mite specimens in samples (in qualitative analyses). Decrease in the frequency of occurrence at a local scale in long-term studies (e.g., a national park or nature reserve), at a macro-scale (any administrative unit or country), or globally (in the whole area of a continent or geographical region) means that the existence of the species is threatened. A relegation of a species from category F5 (euconstants; frequency/constancy in samples $>50 \%$ ) (frequency indexes after Błoszyk 1999) and F4 (constants; frequency/constancy in samples 30.1-50\%) to F3 (subconstants; frequency/constancy in samples 15.1-30\%) allows to label it as 'vulnerable' (VU). This means a considerable decrease in the number of the local populations in the natural environment. The decrease of this zoocenological parameter to F2 (accessory species; frequency/constancy in samples 5.1-15\%) allows to assign the species to the category 'endangered' (EN), and when it can be given F1 (accidents; frequency/constancy in samples 5.1-15\%) the species has the status of 'critically endangered' (CR). If a species occurs in samples at F2 or F1, it is usually stenotopic or oligotopic (this is evident in the habitat preferences of the species), which means that such species are very vulnerable to any detrimental change in environmental conditions.

\section{Criterion B: geographic range}

It is hard to establish the exact area of occurrence of invertebrates in the natural environment (Niedbała 2000; André et al. 2002; Lewis and Senior 2011). In the case of soil mites it depends on the extent to which a given area has been examined. The range of occurrence in a given area is determined by the most distant ground plots. In the case of data from other studies than our own, a ground plot can be considered reliable if a large number of specimens was found in it during one collecting session, or if the session is repeated at least twice. Single specimens of a species found beyond the range of occurrence or synanthropic environments (such as parks, agrocenoses, and urbanized areas) should always be considered with great caution. It is possible that the specimens of a given species found in such places had been introduced there by humans, and it is very unlikely that a population will survive in that place. Monographs and catalogues can be valuable sources of information about distribution of species of invertebrates (usually in the area of a country). As for Poland, Monografie Fauny Polski [Monographs of Polish Fauna] and Katalog Fauny Polski [Catalogue of Polish Fauna] seem to be reliable sources of information. Volumes that provide information about the exact locations where specimens were collected or that contain maps with the distribution of described species are extremely valuable (Błaszak 1974; Niedbała 1976; Błoszyk 1999). Lists of species compiled for a given country, usually with no information about the abundance, frequency of occurrence, and distribution, are of course far less informative (Hirschmann and Hutu 1974; Hirschmann 1979; Wiśniewski and Hirschmann 1993). Nowadays the global positioning system (GPS) allows to localize precisely the places of sample collection, and computer software, as well as GPS systems, can visualize the distribution of whole local populations, or even single specimens (Błoszyk et al. 2013). Thus, it is possible to establish precisely the area and range of occurrence of a species. This in turn means that regular monitoring of the range of occurrence of a species can tell whether it remains within the range, it is retrieving from a 
place colonized earlier, or is expanding. As it is impossible to establish the exact boundaries of the range for invertebrates, we claim that in the case of soil fauna (especially soil mites) the range becomes narrower or broader when during a period of 10 years the most distant ground plots (which mark the range) for a given species retracted or move further for at least $20 \mathrm{~km}$, which is twice the basic unit of the UTM grid $(10 \times 10 \mathrm{~km})$.

\section{Criterion C: small population size and decline}

Cardoso et al. (2011) claim that the current abundance limits for populations of invertebrates proposed by IUCN are not reasonable because the values are too low and irrelevant to the abundance of invertebrates, and the use of these values can lead to underestimation of the extinction threat - the claim seems to be valid. Even a very high abundance of a species does not protect it against extinction. This is true for both vertebrates (e.g., the passenger pigeon) and invertebrates (e.g., ants, termites, wasps) (Dorst and Sikora 1971), as it is quite easy to cause extinction of a large local population. In the case of mites, for example, abundance of mites in dead wood can be very high, but if the wood is removed from the forest, the species will be taken away with the wood, as well as many other saproxylic and cortical invertebrates (Stokland et al. 2012). Other examples are species inhabiting bird nests, small mammals, or excrements of big vertebrates (see e.g. Napierała and Błoszyk 2013). Thus, regardless of the current abundance, species that live in specific unstable and isolated microhabitats should be also regarded as threatened.

\section{Criterion D: very small or restricted population}

Assuming that it would be possible to estimate their actual abundance, for mites it would be insufficient to accept the current species abundance limits: 'critically endangered if $n$ (number of specimens) $<50$, endangered if $\mathrm{n}<250$, and vulnerable if $\mathrm{n}<1000$, or AOO (area of occupancy) $<20 \mathrm{~km}^{2}$ or $\leq 5$ locations ' - these limits would lead to underestimation of the conservation status. For example, Metagynella paradoxa has been found only twice in Poland in over 2000 samples of dead wood and wood galleries under tree bark (Błoszyk, unpubl. data), but in each case the number of specimens was quite large ( $>50$ and $>250$ ). This species would seem to be extremely threatened due to the low number of places where it has been found so far. Moreover, the habitat of this species is exposed to destruction by felling old trees and these very rare populations could have been destroyed.

\section{Criterion E: quantitative analysis of extinction risk}

As has been pointed out by Cardoso et al. (2011), the criterion 'Quantitative analysis of extinction risk' should also take into account the possibility of habitat destruction. This is important especially in the case of stenotopic species, which occur mainly in unstable microhabitats, or habitats that are liable to frequent transformations (e.g., due to human activity). Many species of mites have very specific preferences for only one type of unstable microhabitat, and for this reason they often occur only in this particular type of microhabitat, where they form communities, very unique in their species composition and dominance structure (Napierała and Błoszyk 2013). The occurrence of such species in forest ecosystems increases the biodiversity of Uropodina in such communities by onethird (Błoszyk 1999; Błoszyk et al. 2003b; Napierała and Błoszyk 2013). On the other hand, cutting down 10 ha of one of the largest remaining parts of the primeval forest in 
Puszcza Białowieska (NE Poland) eliminates most of the litter species of mites from the suborder Uropodina, and reconstruction of such as community in a hornbeam forest would take roughly 80-120 years (Błoszyk unpubl. data). Furthermore, the IUCN criteria do not take into consideration the fact that estimating the probability of extinction of a particular number of specimens in a given period of time is extremely hard (Akçakaya et al. 2006). It should be borne in mind that abundance of invertebrates can fluctuate considerably (daily, seasonally, and annually). For this reason it is impossible to state definitely whether changes in abundance observed at a given time are not a reaction to changes in environmental conditions. In the case of invertebrates, frequency of occurrence of a species in a certain environment seems to be a much better criterion.

Based on the criteria adduced above, we present an evaluation of the conservation status for Uropodina species found in Poland. This is in fact a first Red List for mites inhabiting central Europe. Our evaluation embraces the whole area of Poland.

\section{Results and discussion}

\section{The IUCN classification of mites from the suborder Uropodina}

The current study offers new criteria of classification for soil fauna, resting on nomenclature of the IUCN categories. The EnI index calculated for all Uropodina species listed in the study fluctuated between 5 and 26 (Table 2). The analysis of the EnI values allowed to distinguish different classes of this index, which were later converted to the IUCN criteria (Table 2, Fig. 2).

\section{Evaluation of abundance and frequency of selected species}

Out of the 93 species of Uropodina found in Poland only four can be regarded as common (Tables 3, 4). These are Trachytes aegrota, Olodiscus minima, Oodinychus ovalis

Table 2 Number of species (N) and their share (\%) in different classes of EnI index (see Fig. 2 for explanation of the Red List categories)

\begin{tabular}{lcrrrrrrrrrrrrrrrrr}
\hline RL category & Sum & 5 & 6 & 9 & 10 & 11 & 12 & 13 & 14 & 15 & 17 & 19 & 20 & 21 & 23 & 24 & 26 & Total \\
\hline EX? & $\mathrm{N}$ & 1 & 0 & 0 & 0 & 0 & 0 & 0 & 0 & 0 & 0 & 0 & 0 & 0 & 0 & 0 & 0 & 1 \\
& $\%$ & 100 & 0 & 0 & 0 & 0 & 0 & 0 & 0 & 0 & 0 & 0 & 0 & 0 & 0 & 0 & 0 & \\
CR & $\mathrm{N}$ & 23 & 3 & 0 & 0 & 0 & 0 & 0 & 0 & 0 & 0 & 0 & 0 & 0 & 0 & 0 & 0 & 26 \\
& $\%$ & 88 & 12 & 0 & 0 & 0 & 0 & 0 & 0 & 0 & 0 & 0 & 0 & 0 & 0 & 0 & 0 & \\
EN & $\mathrm{N}$ & 0 & 0 & 1 & 12 & 0 & 0 & 0 & 0 & 0 & 0 & 0 & 0 & 0 & 0 & 0 & 0 & 13 \\
& $\%$ & 0 & 0 & 8 & 92 & 0 & 0 & 0 & 0 & 0 & 0 & 0 & 0 & 0 & 0 & 0 & 0 & \\
VU & $\mathrm{N}$ & 0 & 0 & 0 & 0 & 25 & 8 & 0 & 0 & 0 & 0 & 0 & 0 & 0 & 0 & 0 & 0 & 33 \\
& $\%$ & 0 & 0 & 0 & 0 & 76 & 24 & 0 & 0 & 0 & 0 & 0 & 0 & 0 & 0 & 0 & 0 & \\
NT & $\mathrm{N}$ & 0 & 0 & 0 & 0 & 0 & 0 & 5 & 5 & 0 & 0 & 0 & 0 & 0 & 0 & 0 & 0 & 10 \\
& $\%$ & 0 & 0 & 0 & 0 & 0 & 0 & 50 & 50 & 0 & 0 & 0 & 0 & 0 & 0 & 0 & 0 & \\
\multirow{2}{*}{ LC } & $\mathrm{N}$ & 0 & 0 & 0 & 0 & 0 & 0 & 0 & 0 & 2 & 1 & 1 & 2 & 1 & 1 & 1 & 1 & 10 \\
& $\%$ & 0 & 0 & 0 & 0 & 0 & 0 & 0 & 0 & 20 & 10 & 10 & 20 & 10 & 10 & 10 & 10 & \\
\multirow{2}{*}{ Total } & $\mathrm{N}$ & 24 & 3 & 1 & 12 & 25 & 8 & 5 & 5 & 2 & 1 & 1 & 2 & 1 & 1 & 1 & 1 & 93 \\
\hline
\end{tabular}




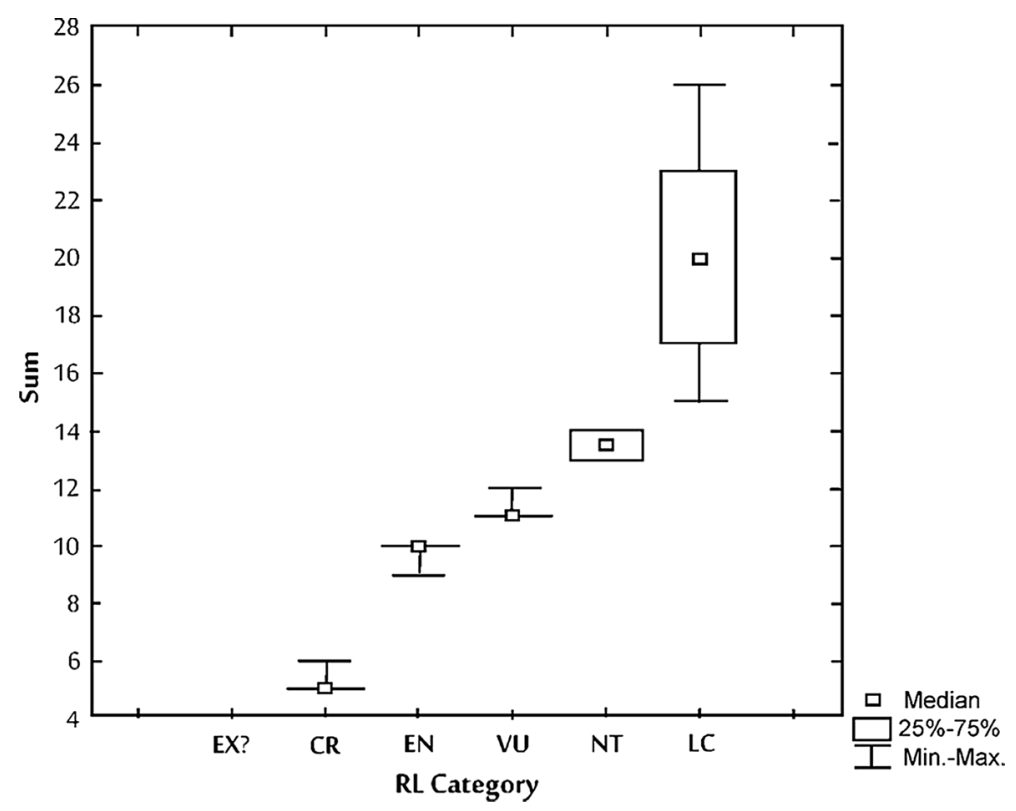

Fig. 2 Values of EnI index converted into IUCN categories: EX (extinct) $=\mathrm{EnI}<9$ and species has not been recorded for at least 65 years; CR (critically endangered) $=\mathrm{EnI}<9$; EN (endangered) = EnI 9-10; VU (vulnerable $)=$ EnI 11-12; NT $($ near threatened $)=$ EnI 13-14; LC $($ least concern $)=$ EnI $>14$

and Urodiaspis tecta, which are eurytopic or polytopic species (Błoszyk 1999). Trachytes irenae and Oodinychus karawaiewi were also abundant, though they were found in fewer locations-T. irenae occurs only in the south of Poland, where the species has its northern range, whereas $O$. karawaiewi occurs mainly in areas with strong anthropopressure (Błoszyk 1999; Błoszyk et al. 2006a, b). None of the species was exceptionally abundant and rare at the same time. Trachytes pauperior, which has very specific preferences for soil moisture, was abundant and frequent in the whole area of Poland, as is Dinychus perforatus, which also has very specific preferences for soil moisture, though occurs far less frequently - both species occur mainly in litter and soil of various forest ecosystems (Błoszyk 1999).

Another group comprises species which form abundant local populations, but they occur fairly rarely (Table 3). Among these species are Janetiella pulchella, Leiodinychus orbicularis and Phaulodiaspis borealis. All these species occur in unstable microhabitats: J. pulchella occurs in dead wood merocenoses, L. orbicularis in bird nests, and P. borealis in burrows of the common mole (Talpa europaea) (Błoszyk 1999; Błoszyk et al. 2003a, b, 2015; Bajerlein and Błoszyk 2004; Napierała and Błoszyk 2013; Napierała et al. 2016). Urodiaspis pannonica, which occurs mainly in forests, was sparse and apparently sporadic in the whole area of Poland (Table 3) (Błoszyk 1999). Species like Janetiella pyriformis, Neodiscopoma splendida, Apionoseius infirmus, Nenteria breviunguiculata, and Dinychus carinatus are even less frequent. Only $N$. splendida is a soil species with interesting disjunctive geographical distribution, with two separate populations in Poland, one in the north and one in the south (Błoszyk 1999; Błoszyk et al. 2003a). The other species from this group occur in unstable merocoenoses: J. pyriformis and D. carinatus occur in tree hollows and different types of dead wood (Błoszyk 1999; Błoszyk et al. 2003a, 2015; 
Table 3 Zoocenological analysis of Uropodina species found in Poland

\begin{tabular}{|c|c|c|c|c|}
\hline \multirow[t]{2}{*}{ Dominance } & \multicolumn{4}{|l|}{ Frequency } \\
\hline & Very frequent & Frequent & Rare & Very rare \\
\hline Very abundant & $\begin{array}{l}\text { T. aegrota, } \\
\text { O. minima }\end{array}$ & O. ovalis, U. tecta & $\begin{array}{l}\text { T. irenae, } \\
\quad \text { O. karawaiewi }\end{array}$ & None \\
\hline Abundant & None & T. pauperior & D. perforatus & $\begin{array}{l}\text { J. pulchella, } \\
\text { L. orbicularis, } \\
\text { P. borealis }\end{array}$ \\
\hline Few & None & None & U. pannonica & $\begin{array}{l}\text { J. pyriformis, } \\
\text { N. splendida, } \\
\text { A. infirmus, } \\
\text { N. breviunguiculata, } \\
\text { D. carinatus }\end{array}$ \\
\hline Very few & None & None & None & The other 76 species \\
\hline
\end{tabular}

Napierała and Błoszyk 2013), whereas A. infirmus and N. breviunguiculata occur mainly in old nests of predatory birds, as well as white and black storks (Bajerlein et al. 2006; Błoszyk and Gwiazdowicz 2006; Błoszyk et al. 2006a, b). The other 76 species are very sporadic and there are usually very few specimens found. Some of these species have been found so far only in a few locations as single specimens (Table 3).

\section{Evaluation of conservation status}

Evaluation of the conservation status of the 93 species of Uropodina in Poland (Table 4) indicates that one of the evaluated species (Trichouropoda barbatula) has been classified as extinct (EX), 26 species (28\%) have been classified as critically endangered (CR), 13 $(14 \%)$ as endangered (EN), $33(35 \%)$ as vulnerable (VU), $10(11 \%)$ as near threatened (NT), and $10(11 \%)$ as least concern (LC).

\section{Threatening factors}

There are many factors that cause decline in species diversity and population abundance of Uropodina species in Poland, most importantly those directly involved in the destruction of habitats. As most Uropodina mites are forestal species, which prefer litter and soil, especially that of old forests (Athias-Binche 1977a, b, c, 1979, 1981a, b, c, 1982a, b, 1983; Błoszyk 1999; Mašán 2001), the factors that cause detrimental changes leading to degradation of forest ecosystems are the main focus in this study. These include both changes within the area of a forest complex and factors responsible for shrinking and fragmentation of forests. Fragmentation divides forests into separate areas and leads to shrinking of natural habitats (Pullin 2005). One of the biological consequences of forest fragmentation is the loss of the forestal character of these areas, which also means that such areas become prone to anthropopressure (Pullin 2005). This in turn can cause decline or even entire loss of typically forestal stenotopic species. The most important consequence of habitat fragmentation at the population level is that a population of a given species is divided into smaller populations (i.e., local populations). Among the species which have become endangered due to forest fragmentation and degradation are soil mites from the genus Trachytes. The gradual decline of local populations consisting of species from this genus has been observed for the 


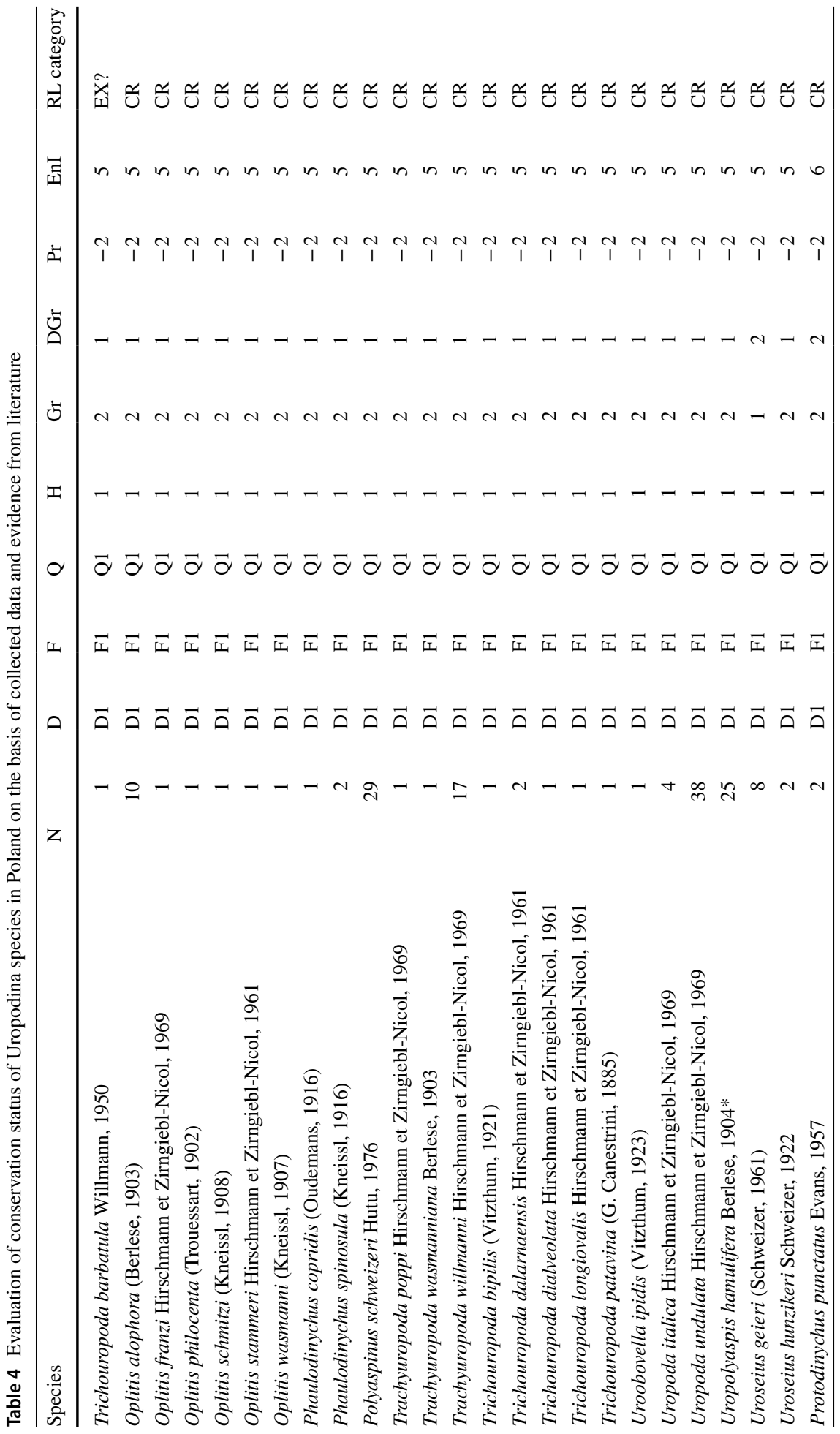




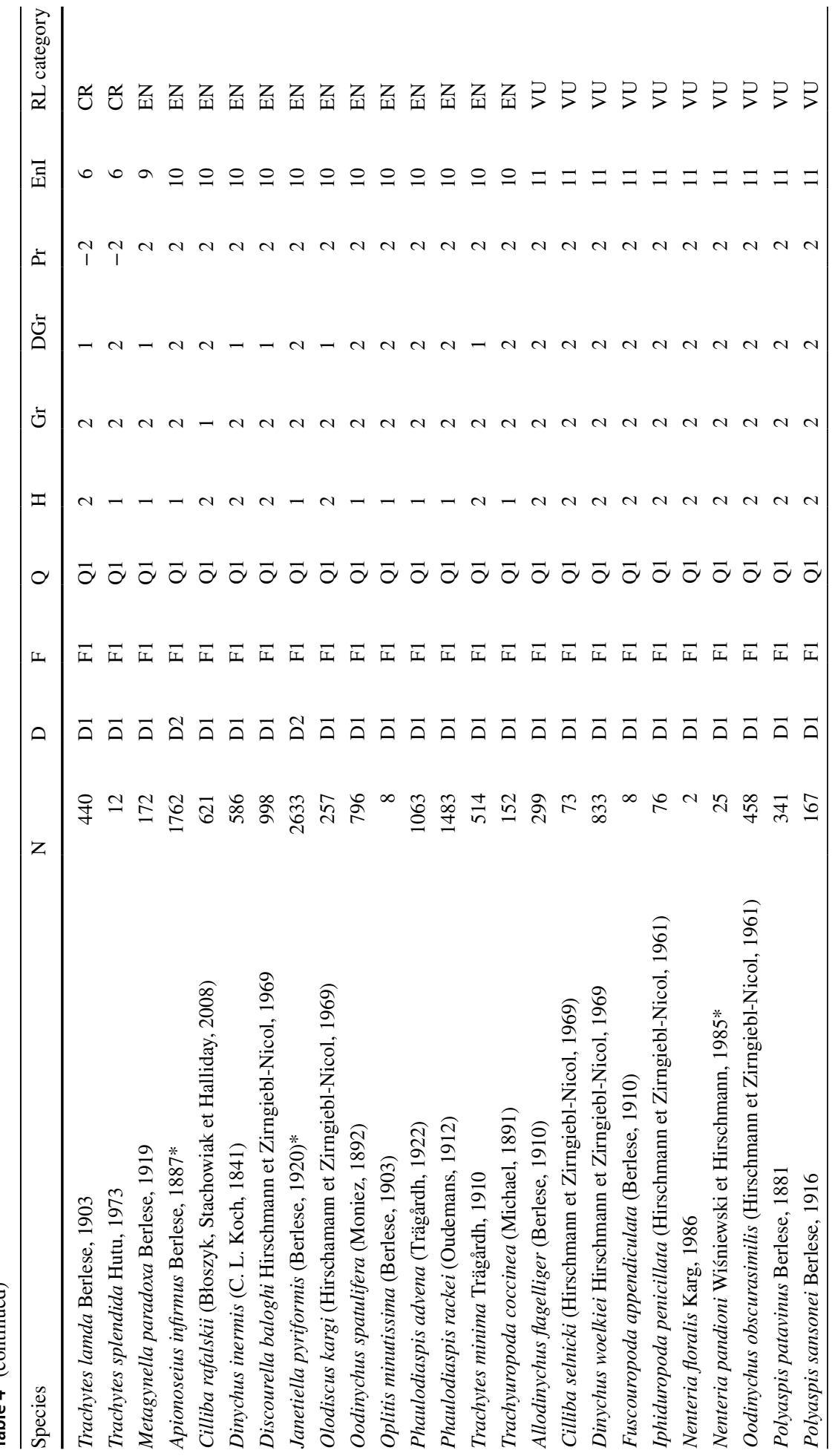




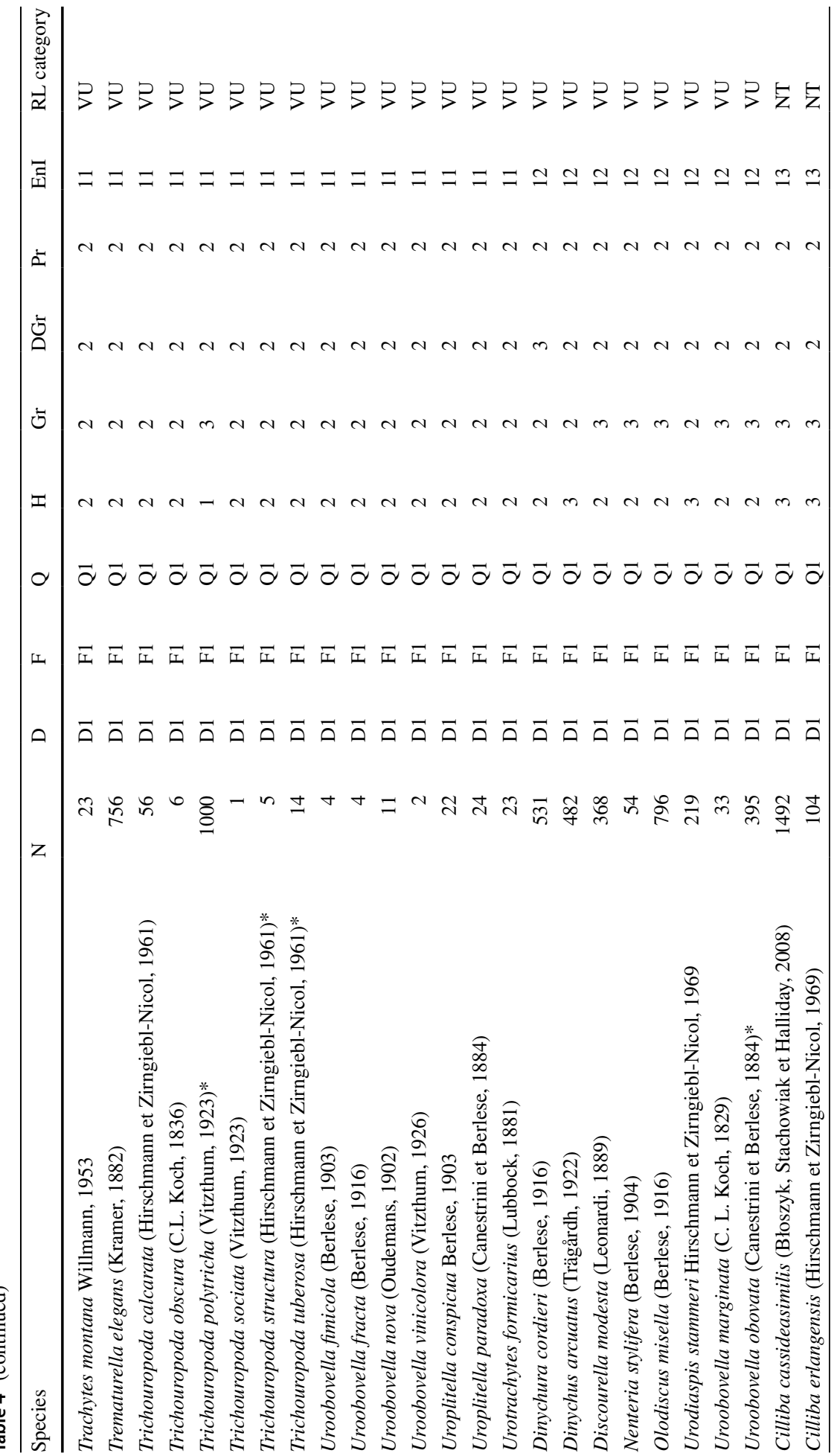




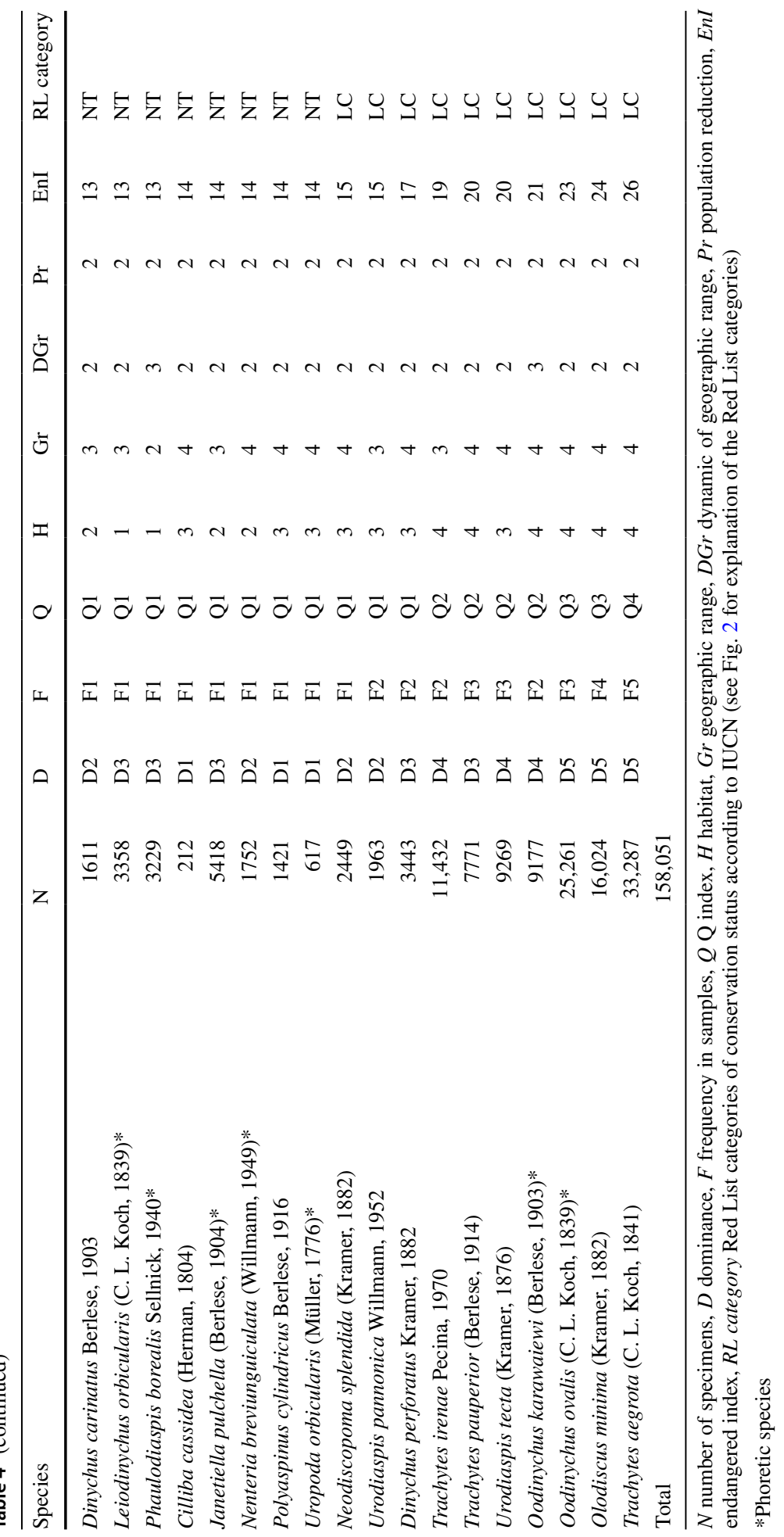


last 40 years (Napierała 2008; Napierała et al. 2015b). One of these species-T. lamdahas been classified as endangered (EN) — a rare species occurring in old (mainly deciduous) forests found so far only in a few distant locations in Poland. Another good example is T. splendida, which is now critically endangered (CR) due to the process of cutting down and shrinking of old forests. Since the second half of the $1980 \mathrm{~s}$ the decline of populations of another rare species inhabiting central Europe-T. minima (EN)—has also been observed (Błoszyk 1999). This species occurred in Poland in two separate populations, in the Carpathians and Sudetes (Błoszyk 1980, 1999). Despite very intensive research the species has not been found in the area of the foothills of the Sudetes since the beginning of the 1990s. It is likely that this species has already become extinct in this region of Poland. Acid rain and accumulation of cross-border pollution in this region are probably the major two reasons responsible for this extinction. In this period researchers also observed dying of the forests in the Izery Mountains and in the Karkonosze Mountains, which obviously must have had a detrimental impact on the soil fauna in this region (Błoszyk 1995a, b).

Forests consisting of old trees are rich in microhabitat types, especially those containing dead wood. Felling old trees and fragmentation of large forests results in reduction of the living space of species inhabiting unstable microhabitats. For this reason the second group of threatening factors for Uropodina comprises activities which lead to loss or dispersion of merocenoses, which is crucial for many species, as roughly $30 \%$ of the species in Poland have strong habitat preferences for unstable microhabitats (Błoszyk 1999). One of the characteristics of such species is that they are usually abundant, but they are dispersed and occur only in a certain type of merocenosis (Napierała and Błoszyk 2013). The decline of such microhabitats and their scattering make it extremely hard for these small invertebrates to move and find a new appropriate microhabitat, which of course leads to extinction of a population. Although Uropodina mites can transfer from one place to another by means of phoresy (Athias-Binche 1984, 1993, 1994; Faasch 1967; Bajerlein and Błoszyk 2004), and they can quickly colonize new microhabitats, they may not survive when there are very few places with the right habitat conditions or when such places are too far. A good example of a critically endangered (CR) species living in microhabitats is Oplitis alophora. It has been found in dead wood and tree hollows of old beeches in Roztocze (SE Poland). The species is very rare and sparse mainly because it occurs locally and the old beech forests are shrinking. A similar situation applies to Iphiduropoda penicillata, which is endangered due to extensive and uncontrolled deforestation of old forests. This species is rare and not abundant in its preferred habitats dead wood, tree hollows of old deciduous forests, and nests of predatory birds. A solution to this problem in Polish forestry will be a law that allows to leave dead wood in forests, which will increase the abundance and biodiversity of the species inhabiting dead wood. However, such solutions require a lot of time because Uropodina prefer old trees which are over 100 years old (Błoszyk 1999; Napierała 2008; Napierała et al. 2009).

Besides dead wood, Uropodina also live in other merocoenoses, for example, nests of birds and mammals, as well as anthills (Błoszyk 1999; Wiśniewski and Hirschmann 1993; Mašán 2001; Bajerlein et al. 2006; Błoszyk and Gwiazdowicz 2006; Błoszyk et al. 2006a, b; Napierała and Błoszyk 2013). The abundance and diversity of the mite species inhabiting such places is directly dependent on the abundance of the hosts; therefore, any decrease in the number of the host species entails a decrease in the fauna inhabiting the nest, including Uropodina mites. A good example showing this dependency is A. flagelliger, which is quite common in nests of the white stork (Błoszyk et al. 2005, 2006a, b; Błoszyk and Gwiazdowicz 2006). Nests of the white stork are fairly evenly distributed over the whole area of Poland (Kania 2006; Maluśkiewicz and Tomaszewski 2012; Pietrowiak 
2012; Tobółka 2012), and at least $1 / 3$ of them can be inhabited by this mite (Błoszyk and Gwiazdowicz 2006). During the last couple of years people in some countries started to hunt for migrating white stork, especially in Lebanon, which in turn has caused a decrease in the number of nests inhabited by this bird in Poland. This implies shrinkage of habitats for A. flagelliger, probably resulting in an overall decrease in the number of local populations, and thus in a decrease in the whole country. In this situation A. flagelliger should be classified as vulnerable (VU). Similarly, Uroseius hunzikeri inhabits unstable merocenoses, such as nests of birds, burrows of the common mole, nests of bumblebees (Bombus sp.), and soil. This species is usually very sparse and therefore can be classified as critically endangered (CR).

Species inhabiting open environments constitute the smallest group among the Uropodina. Open environments are very rare or exposed to degradation. Trachyuropoda willmanni and T. poppi are good examples-both species inhabit rare xerothermic plant communities and they both have been classified as critically endangered (CR). The decline of xerophilous grasses observed in the last couple of years is caused by the lack of grazing and grass harvesting, which accelerates the natural succession in such areas, and the growing shrubs and trees pose a serious threat to the existence of these species. Also other species are endangered due to the decline of open environments, for example, the hygrophilous species of Uropodina, such as Uropoda undulata and D. inermis. The former lives in peatlands, alder forests and marshy forests, where they form local populations with low abundance. The latter prefers damp meadows, alder forests and marshy forests (Błoszyk 1999). Although $D$. inermis is still very common, it may soon become endangered due to the gradual lowering of the groundwater level, land improvement in damp areas and the draining of swamps and peatlands.

All these threatening factors usually occur at the regional level and they affect most of the Uropodina species. However, soil fauna is also affected by global changes, e.g. climate changes (Napierała et al. 2010). For example, Uroseius gaieri is a postglacial relict which requires low temperature to survive (Błoszyk and Olszanowski 1984). The only population of this species has been found so far on a rock cliff in Szczeliniec. Due to its low abundance and local occurrence, and in light of global warming, this relic species is, with no doubt, endangered and has been assigned to the category CR.

\section{Conclusions}

The IUCN Red List contains only one mite species, namely Scheloribates evanescens, which is a species from the order Oribatida (IUCN Red List of Threatened Species 2017). This species has been given the EN category on the basis of merely eight specimens found in 1967 in two locations on Saint Helena Island (IUCN Red List of Threatened Species 2017). The research into this species has never been repeated and, therefore, it is unknown whether the range of occurrence of the species is really restricted to this small area and whether the species is endemic. Moreover, the research seems questionable because it does not say whether the low number of specimens stems from the fact that the species is rare, or from collection in the least favorable season of natural annual fluctuations, or perhaps the location was not typical for the species. Similar doubts appear in the case of studies with accounts of species of mites found only in one location (e.g., Kontschán 2003). Any attempt at evaluating the conservation status of a species based on only few specimens 
throws the research into question, as the category EN given in the classification may be a result of poor sampling, and it does not necessarily show the actual conservation status.

For the current analysis we had at their disposal data and materials obtained during a long-term research: 16,921 samples collected for over 50 years and a lot of information about the biology and ecology of the analyzed group of mites. This article is in fact the first attempt to compile a Red List for soil mites from the suborder Uropodina inhabiting central Europe. Moreover, this work summarizes 50+years of research into this group of mites in Poland in the context of species conservation. We tried to estimate the current state of Uropodina populations for the listed species on the basis of the IUCN criteria with certain modifications to adapt them to this group of organisms, and to highlight those species that may become endangered in the future. The large number of stenotopic and oligotopic species found in the analyzed material indicates that these mites are vulnerable to any detrimental changes in environmental conditions, which can pose threats to them (Błoszyk 1999; Błoszyk et al. 2003a; Napierała 2008; Napierała et al. 2015b).

The results can also have a broader and more practical application, which is not restricted only to establishing the conservation status of Uropodina species. As mites from this group can be used as bioindicators, Uropodina can be helpful in the monitoring of soil condition (Błoszyk 1998a, b, 1999; Czarnota and Błoszyk 1998; Błoszyk et al. 2003a; Napierała 2008; Napierała and Błoszyk 2013). The Convention on Biological Diversity, signed and ratified by Poland and other countries, imposes a formal obligation to work out strategies, plans, and programs that will focus on protection and monitoring of elements of biological diversity, and to identify processes which may have negative impact on the protection of biological diversity. This obligation forces researchers and institutions responsible for environmental protection to search for methods that will allow the use of faunistic elements for monitoring purposes and to evaluate the condition of the environment, in this case of the soil. The attempts to use Uropodina mites to estimate soil condition in Poland are plentiful, especially for protected areas such as national parks, nature reserves (Błoszyk 1998a, b; Błoszyk and Szymkowiak 1999; Błoszyk and Krysiak 2000; Błoszyk et al. 2002, 2010; Napierała 2008; Napierała et al. 2015b), and places that are extremely valuable from the natural point of view, for example, Puszcza Białowieska, or the largest concentration of yews (Taxus baccata) in Europe (Błoszyk and Olszanowski 1999; Błoszyk and Szymkowiak 1999; Błoszyk, unpubl. data).

Several interesting conclusions have been drawn from the research conducted in Wielkopolska (W Poland) (Napierała 2008). The results of this research show that $80 \%$ of all species of Uropodina in Wielkopolska occurred in nature reserves and in Wielkopolski National Park, and both these places constitute only $2 \%$ of the whole area of the region. The species listed in our Red List have been classified as critically endangered, and they occurred mainly in places legally protected and in areas that are valuable from the natural point of view (Błoszyk 1998a, b; Błoszyk and Olszanowski 1999; Błoszyk and Szymkowiak 1999; Błoszyk and Krysiak 2000; Błoszyk et al. 2002, 2010; Napierała 2008; Napierała et al. 2015b). The results also show that it is extremely important to protect habitats through establishing legally protected areas and rational management of natural resources in order to preserve diversity of soil fauna and other small invertebrates (Jones et al. 2012; Convention on Biological Diversity).

The attempt at compiling a Red List for one of the groups of soil mesofauna on the basis of the modified IUCN criteria is also a response to the statement made by Cardoso et al. (2011), who claim that there is a clear need to fill in the void between the number of invertebrate species whose conservation status has not been evaluated yet and the 
increasing number of new species of invertebrates described in the literature (15,000 every year) (Clarivate analytics ION, Index to Organism Names). In the case of mites the number of species described so far is roughly over 55,000 species (Krantz and Walter 2009), and the number is increasing. We are fully aware of the fact that the results of the research presented here are only a small contribution to the evaluation of the conservation status of soil mites, though such research seems important because it may encourage other researchers and experts to compile similar lists for other groups of invertebrates. The amount of available information on many groups of soil mesofauna may never be sufficient to legally protect these small organisms. However, evaluating the conservation status of at least some of them, especially those already described in the literature, by means of appropriate criteria, with certain modifications if necessary, can show that these small organisms, just like insects or vertebrates, also require legal protection, as they are important elements of many ecosystems. The only effective way of protecting them is by establishing legally protected areas which are most valuable from the natural point of view, regardless of their current legal status.

Acknowledgements Authors would like to thank Ms Joanna Gogol for her help in preparing the manuscript.

Open Access This article is distributed under the terms of the Creative Commons Attribution 4.0 International License (http://creativecommons.org/licenses/by/4.0/), which permits unrestricted use, distribution, and reproduction in any medium, provided you give appropriate credit to the original author(s) and the source, provide a link to the Creative Commons license, and indicate if changes were made.

\section{References}

Akçakaya HR, Butchart SHM, Mace GM et al (2006) Use and misuse of the IUCN Red List Criteria in projecting climate change impacts on biodiversity. Glob Change Biol 12:2037-2043. https://doi. org/10.1111/j.1365-2486.2006.01253.x

André HM, Ducarme X, Lebrun P (2002) Soil biodiversity: myth, reality or conning? Oikos 96:3-24. https://doi.org/10.1034/j.1600-0706.2002.11216.x

Aspetti GP, Boccelli R, Ampollini D et al (2010) Assessment of soil-quality index based on microarthropods in corn cultivation in Northern Italy. Ecol Indic 10:129-135. https://doi.org/10.1016/j.ecoli nd.2009.03.012

Athias-Binche F (1977a) Étude quantitative des Uropodides édaphiques de la hêtraie de la Tillaie en forêt be Fontainebleu (Acarines; Anactinotriches). Rev Écol Biol Sol 15:67-88

Athias-Binche F (1977b) Étude quantitative des Uropodides (Araneis; Anactinotriches) d'un arbre mort de la hêtraie de la Massane. 1—Caratères généraux du peuplement. Vie Milieu 27:157-175

Athias-Binche F (1977c) Donnés sur la niche écologique des Uropodides édaphiques (Acarina: Anactinotrichida). Exemple de la hêtraie de la Tillaie en forêt de Fontainebleau. Ecol Bull Stockholm 25:36-44

Athias-Binche F (1979) Effects of some soil features on a Uropodine mite community in the Massane forest (Pyrénées-Orientales, France). In: Rodriguez (ed) Recent advances in acarology, vol 1. pp 567-573

Athias-Binche F (1981a) Contribution à la connaissance des uropodides libres (Arachnides: Anactnotriches) de quelques écosystèmes forestiers européen. PhD Thesis, Université de Paris

Athias-Binche F (1981b) Différent types de structures des peuplements d'Uropodides édaphiques de trois écosystèmes forestiers (Arachnides: Anactinotriches). Acta Oecol Oecol Gen 2:153-159

Athias-Binche F (1981c) Écologie des Uropodides édaphiques (Arachnides: Parasitiformes) de trois écosystèmes forestiers. 1. Introduction, matérial, biology. Vie Milieu 31:137-147

Athias-Binche F (1982a) Écologie des Uropodides édaphiques (Arachnides, Parasitoformes) des trois écosystèmes forestiers. 3. Abondance et biomasse des microarthropodes du sol, facteurs du milieu, abondance et distribution spatiale des Uropodides. Vie Milieu 32:47-60

Athias-Binche F (1982b) Écologie des Uropodides édaphiques (Arachnides: Parasitiformes) des trois écosystèmes forestiers. 4. Abondance, biomasse, distribution verticale, sténo-et eurytopie. Vie Milieu 32:159-170 
Athias-Binche F (1983) Écologie des Uropodides édaphiques (Arachnides: Parasitiformes) de trois écosystèmes forestiers. 5. Affinités interspécifiques, diversité, structures écologiques et quantitatives des peuplements. Vie Milieu 33:25-34

Athias-Binche F (1984) La phorésie chez les acariens uropodides (Anactinotriches), une stratégie écologique originale. Acta Oecol Oecol Gen 5:119-133

Athias-Binche F (1993) Dispersal in varying environments: the case of phoretic uropodid mites. Can J Zool 71:1793-1798. https://doi.org/10.1139/z93-255

Athias-Binche F (1994) La Phorésie chez les Acariens: Aspects adaptatifs et évolutifs. Editions du Castillet, Perpignan

Bajerlein D, Błoszyk J (2004) Phoresy of Uropoda orbicularis (Acari: Mesostigmata) by beetles (Coleoptera) associated with cattle dung in Poland. Eur J Entomol 101:185-188

Bajerlein D, Błoszyk J, Gwiazdowicz DJ et al (2006) Community structure and dispersal of mites (Acari, Mesostigmata) in nests of the white stork (Ciconia ciconia). Biologia 61:525-530. https:// doi.org/10.2478/s11756-006-0086-9

Błaszak C (1974) Zerconidae (Acari, Mesostigmata) Polski. Państwowe Wydawn. Naukowe, Kraków

Błoszyk J (1980) Rodzaj Trachytes Michael, 1894 (Acari: Mesostigmata) w Polsce. Prace Komisji Biologicznej PTPN 54:5-52

Błoszyk J (1983) Uropodina Polski (Acari: Mesostigmata). Adam Mickiewicz University, Poznań

Błoszyk J (1984) Pionowe zróżnicowanie fauny Uropodina Polski. Przegl Zool 28:68-70

Błoszyk J (1985) Materiały do znajomości roztoczy gniazd kreta (Talpa europaea L.) I. Uropodina (Acari, Mesostigmata). Przegl Zool 29:171-177

Błoszyk J (1995a) Ubóstwo gatunkowe i niska liczebność zespołów roztoczy z kohorty Uropodina (Acari: Anactinotrichida) Karkonoszy—wynik naturalnych uwarunkowań, czy tez degradacji srodowiska? In: Sarosiek J (ed) Geoekologiczne problemy Karkonoszy: materiały z sesji naukowej w Borowicach, 13-15.X.1994. Acarus, Poznań, pp 161-168

Błoszyk J (1995b) Rozmieszczenie wybranych gatunków roztoczy (Acari) jako odzwierciedlenie stanu środowiska naturalnego na przykładzie Karkonoskiego Parku Narodowego i Gór Izerskich. In: Sarosiek J (ed) Geoekologiczne problemy Karkonoszy: materiały z sesji naukowej w Borowicach, 13-15.X.1994. Acarus, Poznań, pp 169-172

Błoszyk J (1998a) Próba oceny stanu środowiska glebowego Gorczańskiego Parku narodowego w oparciu o wybrane grupy fauny glebowej i siatkę stałych powierzchni monitoringowych. Przegl Przyr 9:171-180

Błoszyk J (1998b) Roztocze glebowe (Acari) jako bioindykatory wartości przyrodniczej obszarów i obiektów chronionych. Przegl Przyr 9:109-118

Błoszyk J (1999) Geograficzne i ekologiczne zróżnicowanie zgrupowań roztoczy z kohorty Uropodina (Acari-Mesostigmata) w Polsce. I Uropodina lasów grądowych (Carpinion betuli). Wydawnictwo Kontekst, Poznań

Błoszyk J (2008) Uropodina. In: Bogdanowicz W, Chudzicka E, Pilipiuk I, Skibińska E (eds) Fauna of Poland-characteristics and checklist of species. Museum and Institute of Zoology at the Polish Academy of Sciences, Warszawa, pp 61-64

Błoszyk J, Gwiazdowicz DJ (2006) Acarofauna of nests of the White Stork Ciconia ciconia, with special attention to mesostigmatid mites. In: Tryjanowski P, Sparks TJ, Jerzak L (eds) The White Stork in Poland: studies in biology, ecology and conservation. Bogucki Wydawnictwo Naukowe, Poznań, pp 407-414

Błoszyk J, Krysiak D (2000) Uropodina (Acari: Mesostigmata) rezerwatu "Cisy Staropolskie im. Leona Wyczółkowskiego" w Wierzchlesie. Parki Nar Rez Przyr 19:115-121

Błoszyk J, Olszanowski Z (1984) Uroseius (Apionoseius) gaieri (Schweitzer, 1961) nowy dla fauny Polski gatunek roztocza (Acari, Uropodina). Przegl Zool 28:491-496

Błoszyk J, Olszanowski Z (1999) Materiały do znajomości akarofauny Puszczy Białowieskiej II. Uropodina (Acari: Mesostigmata). Parki Nar Rez Przyr 18:41-52

Błoszyk J, Szymkowiak P (1999) Próba zwaloryzowania wartości przyrodniczych środowiska glebowego rezerwatów cisowych w Borach Tucholskich, w oparciu o analizę zgrupowań roztoczy z kohorty Uropodina (Acari: Mesostigmata). In: Materiały z VI konferencji krajowej z cyklu Kompleksowe Badania i Ochrona Środowiska Naturalnego, Tleń, 14-15 grudzień 1998. Akademia TechnicznoRolnicza im. J.J. Śniadeckich w Bydgoszczy. Wydział Budownictwa i Inżynierii Środowiska, Katedra Kształtowania i Ochrony Środowiska, Bydgoszcz, pp 7-22

Błoszyk J, Bajaczyk R, Błoszyk G, Napierała A (2002) Uropodina (Acari: Mesostigmata) parków narodowych Polski na tle innych obszarów. Kosmos 51:463-470

Błoszyk J, Bajaczyk R, Markowicz M, Gulvik M (2003a) Geographical and ecological variability of mites of the suborder Uropodina (Acari: Mesostigmata) in Europe. Biol Lett 40:15-35 
Błoszyk J, Krysiak D, Napierała A, Markowicz-Rucińska M (2003b) 1.3. Ocena stanu środowiska glebowego wybranych rezerwatów leśnych województwa wielkopolskiego w oparciu o zgrupowania roztoczy z podrzędu Uropodina (Acari: Mesostigmata). In: 1. Ochrona przyrody. Raport o stanie środowiska w Wielkopolsce w roku 2001. Biblioteka Monitoringu Środowiska, pp 21-31

Błoszyk J, Adamski Z, Napierala A, Dylewska M (2004) Parthenogenesis as a life strategy among mites of the suborder Uropodina (Acari: Mesostigmata). Can J Zool 82:1503-1511. https://doi. org/10.1139/z04-133

Błoszyk J, Gwiazdowicz DJ, Bajerlein D, Halliday B (2005) Nests of the white stork Ciconia ciconia (L.) as a habitat for mesostimatic mites (Acari: Mesostigmata). Acta Parasitol 50:171-175

Błoszyk J, Bajerlein D, Gwiazdowicz D et al (2006a) Uropodine mite communities (Acari: Mesostigmata) in birds' nest in Poland. Belg J Zool 136:145-153

Błoszyk J, Krysiak D, Napierała A, Dylewska M (2006b) Can soil fauna undergo synantropisation. In: Gabryś G, Ignatowicz S (eds) Advances in Polish Acarology. SGGW, Warszawa, pp 26-37

Błoszyk J, Napierała A, Jankowiak A et al (2010) Stability of Uropodina mites communities (Acari: Mesostigmata) in natural reserve "Cisy Staropolskie im. Leona Wyczołkowskiego" in Wierzchlas based on long-time observation. Badania Fizjograficzne Seria C-Zoologia 01(51):63-70

Błoszyk J, Nowak M, Mokrowiecka A (2013) Rozmieszczenie roztoczy z podrzędu Uropodina (Acari: Mesostigmata) w Gorczańskim PN. In: Kalinowska-Szymczak A (ed) Kalejdoskop GIS. Esri Polska, Warszawa, pp 88-89

Błoszyk J, Markowicz M, Labijak B et al (2015) Microgeographic diversity of Uropodina (Acari Mesostigmata) communities in dead wood and tree hollows. Redia 98:3-12

Bogdanowicz W, Chudzicka E, Pilipiuk I, Skibińska E (2008) Fauna of Poland-characteristics and checklist of species. Museum and Institute of Zoology at the Polish Academy of Sciences, Warszawa

Cardoso P, Borges PAV, Triantis KA et al (2011) Adapting the IUCN Red List criteria for invertebrates. Biol Conserv 144:2432-2440

Clarivate Analytics ION: Index to Organism Names. http://www.organismnames.com/. Accessed 11 Oct 2017

Convention on Biological Diversity. https://www.cbd.int/convention/. Accessed 11 Oct 2017

Czarnota P, Błoszyk J (1998) Roztocze glebowe z kohorty Uropodina i Labidostommatina jako indykatory zasadności renaturalizacji lasu w Gorczańskim Parku Narodowym. Przegl Przyr 9:119-126

Chapman DA (2009) Numbers of living species in Australia and the world, 2nd edn. Australian Biological Resources Study, Canberra

Dorst J, Sikora Z (1971) Zanim zginie przyroda. PW. Wiedza Powszechna, Warszawa

El-Banhawy EM, El-Borolossy MA, El-Sawaf BM, Afia SI (1998) Biological aspects and feeding behaviour of the predacious soil mite Nenteria hypotrichus (Uropodina: Uropodidae). Acarologia 38:357-360

European Commission (2011) Biodiversity Strategy-Environment-European Commission: Communication from the Commission to the European Parliament Council, the European Economic and Social Committee and Committee of the Regions. Our life insurance, out natural capital: an EU biodiversity strategy to 2020. http://ec.europa.eu/environment/marine/pdf/1_EN_ACT.pdf. Accessed 11 Aug 2017

European Commission (2017) European Red List. http://ec.europa.eu/environment/nature/conservation/ species/redlist/index_en.htm. Accessed 17 Oct 2017

Faasch H (1967) Beitrag zur Biologie der einheimischen Uropodiden Uroobovella marginata, C.L. Koch 1839 und Uropoda orbicularis, O.F. Müller 1776 und experimentelle Analyse ihres Phoresieverhaltens. Zool Jarhb Syst Bd 94:521-608

Gabryś G (1996) Microtrombidiidae (Acari: Actinedida) of Poland. Rocznik Muzeum Górnośląskiego w Bytomiu Entomologia 6-7:145-242

Gabryś G, Mąkol J (1995) Erythraeid (Acari, Actinedida, Erythraeidae) fauna of three zoogeographic regions in Poland. Acta Zool Fenn 196:382-384

Gardi C, Tomaselli M, Parisi V et al (2002) Soil quality indicators and biodiversity in northern Italian permanent grasslands. Eur J Soil Biol 38:103-110. https://doi.org/10.1016/S1164-5563(01)01111-6

Głowaciński Z, Nowacki J (eds) (2004) Polska czerwona księga zwierząt: bezkręgowce= Polish red data book of animals: invertebrates. Instytut Ochrony Przyrody PAN; Akademia Rolnicza im. Cieszkowskiego, Kraków: Poznań

Gwiazdowicz DJ (2000) Mites (Acari, Gamasida) associated with insects in the Białowieża National Park. Acta Parasitol 45:43-47

Gwiazdowicz DJ (2007) Ascid mites (Acari, Mesostigmata) from selected forest ecosystems and microhabitats in Poland. Wydawnictwo Akademii Rolniczej im. Augusta Cieszkowskiego, Poznań 
Hirschmann W (1979) Ergänzung der von Hirschmann, Huţu 1974 und Wiśniewski 1978 veröffentlichten Listen der Uropodiden der Erde, geordnet nach dem Gangsystem und nach den Ländern in zoogeographischen Reichen und Unterreichen. Acarologie 26:74-84

Hirschmann W, Huţu M (1974) Uropodiden-Forschung und die Uropodiden der Erde, geordnet nach dem Gangsystem und nach dem Länderen in zoogeographischen Reichen und Unterreichen. Acarologie 20:6-36

Ito Y (1971) Predation by manure-inhabiting mesostigmatids (Acarina: Mesostigmata) on some freeliving nematodes. Appl Entomol Zool 6:51-56

IUCN (2001) Categories and Criteria version 3.1. http://www.iucnredlist.org/static/categories_crite ria_3_1. Accessed 19 July 2017

IUCN Red List of Threatened Species (2017) Summary Statistics. In: IUCN Red List of Threatened Species 2017-2. http://www.iucnredlist.org/about/summary-statistics. Accessed 11 Oct 2017

Jeffery S, Gardi C (2010) Soil biodiversity under threat—a review. Acta Soc Zool Bohem 74:7-12

Jones A, Panagos P, Barcelo S et al (2012) The state of soil in Europe-a contribution of the JRC to the European Environment Agency's environment state and outlook report-SOER 2010. No EUR 25186 EN 80. https://doi.org/10.2788/77361

Kaczmarek S, Seniczak S (1994) Wpływ zanieczyszczeń emitowanych przez Zakłady Azotowe Włocławek na zgrupowania Gamasida (Acari) w glebach boru świeżego. Zeszyty Naukowe Akademii Techniczno-Rolniczej w Bydgoszczy Zootechnika 186:125-132

Kaczmarek S, Seniczak S (1998) Soil Gamasida (Acari) associated with young Scots pine forests polluted by the "Wistom" chemical factory. Zeszyty Naukowe Akademii Techniczno-Rolniczej w Bydgoszczy Ochrona Środowiska 214:203-206

Kaliszewski M, Sell D (1990) Tarsonemus fusarii Cooreman i Tarsonemus parafusarii Kaliszewski (Acari: Tarsonemidae) w Polsce, ze szczególnym uwzględnieniem ekologii. Zeszyty Probl Post Nauk Roln 373:195-216

Kania W (2006) Movement of Polish White Storks Ciconia ciconia - an analysis of ringing results. In: Tryjanowski P, Sparks TJ, Jerzak L (eds) The White Stork in Poland: studies in biology, ecology and conservation. Bogucki Wydawnictwo Naukowe, Poznań, pp 249-294

Karg W (1993) Acari (Acarina), Milben Parasitiformes (Anactinochaeta) Cohors Gmasina Leach, Raubmilben. In: Die Tierwelt Deutschlands, 2nd edn. Gustav Fischer Verlag, Jena, pp 1-523

Kasprzak K, Niedbała W (1981) Wskaźniki biocenotyczne stosowane przy porządkowaniu i analizie danych w badaniach ilościowych. In: Górny M, Grum L (eds) Metody stosowane w zoologii gleby. Wyd. Naukowe PWN, Warszawa, pp 397-416

Kaźmierski A (1980) Materiały do znajomości fauny Tydeidae (Acari: Prostigmata) w Polsce. I. Rodzaj Lorryia Oudemans. Prace Komisji Biologicznej PTPN 54:87-129

Koehler HH (1997) Mesostigmata (Gamasina, Uropodina), efficient predators in agroecosystems. Agric Ecosyst Environ 62:105-117

Koehler HH (1999) Predatory mites (Gamasina, Mesostigmata). Agric Ecosyst Environ 74:395-410

Kontschán J (2003) Deraiophorus Canestrini, 1897 species (Acari: Uropodina) from Borneo. Folia Ent Hung 64:19-25

Kozlowski G (2008) Is the global conservation status assessment of a threatened taxon a utopia? Biodivers Conserv 17:445-448

Krantz GW, Walter DE (2009) A manual of acarology, 3rd edn. Texas Tech University, Texas

Lewis OT, Senior MJM (2011) Assessing conservation status and trends for the world's butterflies: the Sampled Red List Index approach. J Insect Conserv 15:121-128

Mąkol J (2005) Trombidiidae: (Acari: Actinotrichida: Trombidioidea) of Poland. Natura Optima Dux Foundation: Museum and Institute of Zoology. Polish Academy of Sciences, Warszawa

Malmström A, Persson T, Ahlström K et al (2009) Dynamics of soil meso- and macrofauna during a 5-year period after clear-cut burning in a boreal forest. Appl Soil Ecol 43:61-74

Maluśkiewicz M, Tomaszewski P (2012) Populacja lęgowa bociana białego Ciconia ciconia na pradolinowym odcinku doliny Noteci w roku 2011. Ptaki Wielkop 1:102-109

Mašán P (2001) Mites of the cohort Uropodina (Acarina, Mesostigmata) in Slovakia. Annot Zool Bot 223:1-321

Michocka S (1987) Polskie roztocze (Acari) z rodzin Bdellidae i Cunaxidae. Państwowe Wydawn. Naukowe, Warszawa-Kraków

Migliorini M, Pigino G, Bianchi N et al (2004) The effects of heavy metal contamination on the soil arthropod community of a shooting range. Environ Pollut 129:331-340

Moore JC, Snider RJ, Robertson LS (1984) Effects of different management practices on Collembola and Acarina in corn production systems. I. The effects of no-tillage and Atrazine. Pedobiol 26:143-152 
Napierała A (2008) Struktura zgrupowań i rozkład przestrzenny Uropodina (Acari: Mesostigmata) w wybranych kompleksach leśnych Wielkopolski. PhD Thesis, Adam Mickiewicz University, Poznań, Poland

Napierała A, Błoszyk J (2013) Unstable microhabitats (merocenoses) as specific habitats of Uropodina mites (Acari: Mesostigmata). Exp Appl Acarol 60:163-180. https://doi.org/10.1007/s10493-013-9659-9

Napierała A, Błoszyk J, Bruin J (2009) Communities of uropodine mites (Acari: Mesostigmata) in selected oak-hornbeam forests of the Wielkopolska region (Poland). Exp Appl Acarol 49:291-303

Napierała A, Błoszyk J, Gołdyn B (2010) Are the long-term fluctuations of the number and community structure of Uropodina (Acari: Mesostigmata) in Poland an effect of the climate changes and anthropogenic transformations of environment, or natural fluctuations? In: Morales GJ, Castihlo RC, Flechtmann CHW (eds) XIII international congress of acarology. Recife, Brazil, p 170

Napierała A, Książkiewicz Z, Leśniewska M et al (2015a) Phoretic relationships between uropodid mites (Acari: Mesostigmata) and centipedes (Chilopoda) in urban agglomeration areas. Int J Acarol 41(4):250-258

Napierała A, Labijak B, Skwierczyński F et al (2015b) Influence of habitat type and natural disturbances on uropodine mite communities (Acari: Mesostigmata: Uropodina) in oak-hornbeam forests in Central Europe. Int J Acarol 41:41-52

Napierała A, Mądra A, Leszczyńska-Deja K et al (2016) Community structure variability of Uropodina mites (Acari: Mesostigmata) in nests of the common mole, Talpa europaea, in Central Europe. Exp Appl Acarol 68:429-440

Niedbała W (1972) Sukcesja ekologiczna zgrupowań mechowców (Acari, Oribatei) zadrzewień uroczyska Marcelin w Poznaniu. Prace Komisji Biologicznej PTPN 35:90

Niedbała W (1976) Brachychthoniidae Polski (Acari, Oribatei): studium ekologiczno-faunistyczne. Państ. Wydaw. Naukowe, Warszawa; Kraków

Niedbała W (1990) Structure of soil mite (Acari) communities in urban green of Warsaw. Fragm Faun $33: 21-44$

Niedbała W (2000) Dlaczego przestałem się zajmować ekologią roztoczy glebowych? In: Ignatowicz S (ed) Akarologia polska u progu nowego tysiąclecia. SGGW, Warszawa, pp 193-201

Niedbała W, Błaszak C, Błoszyk J et al (1981) Roztocze (Acari). Fragm Faun 26:1-52

Norton RA, Kethley J, Johnston DE, O'Connor BM (1993) Phylogenetic perspectives on genetic systems and reproductive modes of mites. In: Wrensch D, Ebbert M (eds) Evolution and diversity of sex ratio in insects and mites. Chapman and Hall, London, pp 8-99

Pietrowiak J (2012) Bocian biały Ciconia ciconia na ziemi jarocińskiej w latach 2001-2006. Ptaki Wielkop $1: 76-90$

Pullin AS (ed) (2005) Biologiczne podstawy ochrony przyrody. Wydaw. Naukowe PWN, Warszawa

Rajski A (1967) Autecological-zoogeographical analysis of moss mites (Acari, Oribatei) on the basis of fauna in the Poznan environs. Part I. Bull Entomol Pol 37:69-166

Rajski A (1969) Autecological-zoogeographical analysis of moss mites (Acari, Oribatei) on the basis of fauna in the Poznan environs. Part II. Fragm Faun 14:277-405

Red List Category summary for all animal classes and orders. http://cmsdocs.s3.amazonaws.com/summa rystats/2017-3_Summary_Stats_Page_Documents/2017_3_RL_Stats_Table_4a.pdf. Accessed 10 Apr 2018

Siuda K (1993) Kleszcze Polski (Acari: Ixodida). Cz. 2. Systematyka i rozmieszczenie. Polskie Towarzystwo Parazytologiczne, Warszawa

Stokland JN, Siitonen J, Jonsson BG (2012) Biodiversity in dead wood. Cambridge University Press, Cambridge

Tobółka M (2012) Populacja bociana białego Ciconia ciconia w powiatach kościańskim i gostyńskim w latach 2005-2011. Ptaki Wielkop 1:91-101

Wiśniewski J (1997) Acari-Roztocze. In: Razowski J, Bielańska-Grajner I (eds) Wykaz zwierząt Polski. Wydawnictwo Instytutu Systematyki i Ewolucji Zwierząt PAN, Kraków, pp 202-205

Wiśniewski J, Hirschmann W (1993) Katalog der Ganggattungen Untergattungen, Gruppen and Arten der Uropodiden der Erde. Acarologie 40:1-220 